Original Research Paper

\title{
Upaya Meningkatkan Hasil Belajar Siswa Kelas VII-B MTs Darul Amin Palangka Raya pada Pembelajaran Sejarah Kebudayaan Islam Melalui Metode Information Search
}

\author{
Sapuadi $^{*}$, dan Yana Sari \\ ${ }^{1}$ Program Studi Pendidikan Agama Islam, IAIN Palangka Raya, Palangka Raya, Indonesia \\ ${ }^{2}$ Madrasah Tsanawiyah Darul Amin Palangka Raya,Palangka Raya, Indonesia
}

*Corresponding Author: Sapuadi, Program Studi Pendidikan Agama Islam, IAIN Palangka Raya, Palangka Raya, Indonesia; Email: sapuadi@iain-palangkaraya.ac.id

\section{Pendahuluan}

Kegiatan belajar mengajar pada hakekatnya adalah suatu proses interaksi atau hubungan timbal balik antara guru dan siswa dalam satuan pembelajaran. Guru sebagai salah satu komponen dalam proses belajar mengajar merupakan pemegang peran yang sangat penting. Guru bukan hanya sekedar penyampai materi saja, tetapi lebih dari itu guru dapat dikatakan sebagai sentral pembelajaran, fasilitator, motivator, dan sebagai pengarah bagaimana proses belajar mengajar itu dilaksanakan (Majid, 2017). Oleh karena itu guru harus dapat melaksanakan pembelajaran menjadi lebih efektif dan menarik sehingga bahan pelajaran yang disampaikan dapat membuat siswa merasa senang dan merasa perlu untuk mempelajari bahan pelajaran tersebut.

Ketercapaian tujuan pembelajaran ditentukan oleh banyak faktor di antaranya adalah faktor guru dalam melaksanakan proses belajar mengajar, karena guru secara langsung dapat mempengaruhi, membina dan meningkatkan kecerdasan serta keterampilan siswa (Sinambela, 2017; Inayah, 2013; \&Werdayanti, 2008). Untuk mencapai tujuan pembelajaran secara maksirnal, peran guru sangat penting dan diharapkan guru memiliki metode mengajar yang baik dan mampu memilih model pembelajaran yang tepat dan sesuai dengan konsep-konsep mata pelajaran yang akan disampaikan.

Upaya untuk meningkatkan mutu pendidikan dan pengajaran salah satunya adalah dengan cara memilih strategi atau metode yang tepat dalam menyampaikan materi pelajaran agar dapat meningkatkan hasil belajar siswa khususnya pelajaran Sejarah Kebudayaan Islam. Misalnya, dengan membimbing siswa untuk bersama-sama terlibat aktif dalam proses pembelajaran dan mampu membantu siswa berkembang sesuai dengan taraf intelektualnya akan lebih menguatkan pemahaman siswa terhadap konsep-konsep yang diajarkan. Pemahaman ini memerlukan minat dan motivasi, tanpa adanya minat menandakan bahwa siswa tidak mempunyai motivasi untuk belajar. Oleh karena itu, guru harus memberikan suntikan 
dalam bentuk motivasi sehingga dengan bantuan itu anak didik dapat keluar dari kesulitan belajar.

Berdasarkan hasil studi pendahuluan peneliti di lapangan, rendahnya tingkat hasil belajar banyak dihadapi oleh sejumlah siswa yang tidak memiliki dorongan belajar, sehingga nilai rata-rata mata pelajaran Sejarah Kebudayaan Islam kurang begitu memuaskan. Hal ini disebabkan karena guru dalam proses belajar mengajar hanya menggunakan metode ceramah, tanpa menggunakan media tambahan, dan materi pelajaran tidak disampaikan secara kronologis. Oleh karena itu, dibutuhkan suatu kegiatan yang dilakukan guru dengan upaya membangkitkan motivasi belajar siswa, misalnya dengan membimbing siswa untuk terlibat langsung dalam kegiatan yang melibatkan siswa serta guru yang berperan sebagai pembimbing untuk menemukan konsep Sejarah Kebudayaan Islam.

Merujuk pada permasalahan di atas, diperoleh suatu gambaran bahwa penyebabnya adalah sebagian siswa kurang tertarik untuk belajar Sejarah Kebudayaan Islam dibandingkan dengan eksakta, karena proses pembelajarannya tidak membangkitkan minat siswa untuk belajar. Pelajaran ini lebih banyak hafalan untuk memahami suatu materi pelajaran meskipun didukung dengan afektif pembelajaran. Pengalaman mengajar dan permasalahan yang dijumpai di kelas yakni siswa kurang tertarik belajar sejarah kebudayaan Islam yang berimplikasi terhadap rendahnya hasil belajar siswa. Dengan demikian, diperlukan suatu upaya tindakan guru untuk mengatasi permasalahan pembelajaran agar dapat meningkatkan prestasi belajar.

Salah satu alternatif metode yang dapat digunakan untuk mengaktifkan siswa dikelas adalah metode information search. Metode ini terkait langsung dengan usaha-usaha guru dalam menampilkan pengajaran yang sesuai dengan situasi dan kondisi, sehingga pencapaian tujuan pembelajaran diperoleh secara maksimal. information search berasal dari bahasa Inggris, dari kata information" (informasi) dan search" (mencari/menelusuri) artinya mencari informasi materi yang diajarkan dan diberi kesempatan untuk mencari di dalam atau di luar kelas, seperti perpustakaan, warnet, mencari jurnal dan sumber belajar yang lain. Langkah-langkah pembelajaran metode Information Search antara lain: (a) Guru membagi kelas dalam beberapa kelompok kecil (bisa juga tidak membagi kelompok). (b) Guru membuat pertanyaan-pertanyaan yang jawabannya terdapat dalam teks, buku, dokumen, internet, perangkat keras lainnya. (c) Guru membagikan pertanyaan kepada para siswa. Siswa diminta mencari jawaban dari pertanyaan-pertanyaan yang telah dibuat. Siswa mempresentasikan jawaban dari pertanyaan-pertanyaan. (d) Guru mengulang semua jawaban dari siswa dan mengembangkan jawaban tersebut untuk menambah informasi siswa, sehingga jawaban yang diperoleh semakin jelas.

Penerapan metode information search diharapkan dapat mengatasi kesulitan belajar, meningkatkan kemampuan literasi teknologi siswa untuk mencari informasi sendiri dalam pemecahan masalah yang dihadapi dalam pembelajaran Sejarah Kebudayaan Islam. Metode ini menuntut siswa agar dapat meningkatkan daya pikirnya untuk memecahkan masalah tanpa menggantungkan pada guru dan teman kelompoknya. Hasil penelitian Widyaningrum (2011) menunjukkan bahwa penerapan active learning dengan metode information search untuk meningkatkan aktivitas belajar siswa. Selain itu juga, hasil penelitian Hermanto (2013) bahwa penerapan strategi pembelajaran Information Search dapat meningkatkan minat dan hasil belajar IPS siswa. Melalui model ini, siswa dituntut untuk terlibat aktif dalam kegiatan pembelajaran,mereka dituntut untuk bekerja sendiri dalam memecahkan masalah dan menjawab pertanyaan-pertanyaan yang diberikan oleh guru(Asyachowi, 2011). Upaya ini akan dapat mengembangkan motivasi dalam pembelajaran yang aktif, kreatif dan menyenangkan untuk belajar ke arah yang lebih baik serta akan berimplikasi pada peningkatan hasil belajar siswa.

\section{Metode}

Penelitian Tindakan Kelas (PTK) ini dilaksanakan di kelas VII-B MTs Darul Amin Palangka Raya tahun pelajaran 2016/2017dengan jumlah siswa 39 orang.Penelitian ini telah dilaksanakan pada bulan Februari sampai dengan Maret 2017. Teknik Pengumpulan Data menggunakan (1) Tes: dipergunakan untuk mendapatkan data tentang hasil belajar siswa. (2) Observasi: dilakukan oleh rekan teman sejawat untuk mengumpulkan data tentang partisipasi siswa dalam proses belajar mengajar dan implementasi 
metode information search. Data yang dikumpulkan pada setiap kegiatan observasi dari pelaksanaan siklus PTK dianalisis secara deskriptif dengan menggunakan teknik persentase untuk melihat kecenderungan yang terjadi dalam kegiatan pembelajaran.

Ada dua jenis data yang dikumpulkan penelitian ini yaitu: (1) Data kuantitatif (nilai hasil belajar) yang dapat dianalisis secara deskriptif. Dalam hal ini peneliti menggunakan analisis statistik dekriptif, yaitu untuk mencari presentase keberhasilan belajar. (2) Data kualitatif, yaitu data yang berupa informasi berbentuk kalimat yang memberikan gambaran tentang ekspresi siswa tentang tingkat pemahaman terhadap suatu mata pelajaran (kognitif), pandangan atau sikap siswa terhadap metode belajar yang baru (afektif), aktifitas siswa mengikuti pelajaran, perhatian dan lain-lain yang dapat dianalisis. Dalam penelitian ini, teknik tersebut digunakan untuk menganalisisi data kuantitatif yang diperoleh dari hasil tes pada masing-masing siklus, dan nilai tersebut dihitung jumlahnya dalam satu kelas dan selanjutnya jumlah tersebut dihitung dalam persentase dengan rumus:

$$
\mathrm{NP}=\left(\sum 1 / \sum 2\right) \times 100
$$

Keterangan:

NP: nilai persentase

$\sum$ 1: Jumlah nilai keseluruhan yang diperoleh siswa

$\sum$ 2: Jumlah nilai total maksimum

Penelitian tindakan kelas ini dilaksanakan melalui tiga dengan tahapan masing-masing siklus adalah perencanaan, pelaksanaan, dan refleksi. Pada tahap perencanaan penelitian ini telah dilakukan kegiatan sebagai berikut: (1) Tim peneliti melakukan analisis kurikulum untuk mengetahui kompetensi dasar yang akan disampaikan dalam pembelajaran dengan menggunakan metode yang biasa digunakan oleh guru. (2) Membuat silabus dan rencana pelaksanaan pembelajaran (RPP) dengan mengacu pada tindakan (treatment) yang akan diterapkan dalam PTK. (3) Membuat bahan ajar berbentuk power point dengan pokok bahasan sejarah berdirinya Bani Umayyah. (4) Menyiapkan sarana/media pembelajaran yang akan digunakan dalam proses pembelajaran. (5) Menyusun lembar kegiatan siswa. (6) Membuat lembar format evaluasi. (7) Membuat lembar format observasi.
Tahap pelaksanaan dilakukan dengan penyajian materi pelajaran. Siswa diberikan kesempatan untuk mengajukan pertanyaan dan tanggapan seputar pelajaran SKI materi latar belakang sejarah berdirinya Bani Umayyah.Siswa melakukan pengamatan atau observasi. Guru memberikan penguatan dan menyimpulkan secara bersama-sama dengan siswa. Pada tahap ini juga dilakukan observasi keterlaksanaan pengelolaan pembelajarn menggunakan metode information search serta observasi keaktifan siswa.

Tahap refleksi dilakukan oleh peneliti dengan cara memberikan refleksi terhadap pelaksanaan siklus sebelumnya dan menganalisis serta membuat kesimpulan atas pelaksanaan pembelajaran Sejarah Kebudayaan Islam dengan materi sejarah berdirinya Bani Umayyah dengan metode information search. Hasil refleksi tersebut sebagai acuan peneliti untuk memperbaiki keterlaksanaan metode pembelajaran information search.

\section{Hasil dan Pembahasan}

Penelitian ini telah dilakukan melalui tiga siklus. Hasil dan pembahasan penelitian setiap siklus dapat dijelaskan sebagai berikut:

\section{Siklus I}

Tahap perencanaan pada siklus I meliputi persiapan perangkat pembelajaran yang terdiri dari rencana pelajaran 1 , LKS 1 , soal tes formatif 1 , dan alat-alat pengajaran yang mendukung. Data hasil pengelolaan pembelajaran menggunakan metode information search pada siklus I dapat dilihat pada Tabel 1.

Tabel 1 Pengelolaan Pembelajaran Pada Siklus I

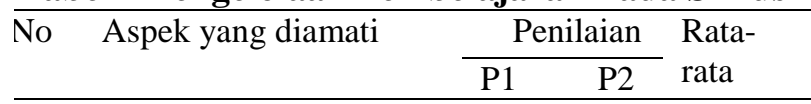

I Pengamatan KBM

A. Pendahuluan

1. Memotivasi siswa $2 \quad 2 \quad 2$

2. Menyampaikan tujuan

322,5

pembelajaran

3. Menghubungkan dengan pelajaran sebelumnya

4. Mengatur siswa dalam kelompokkelompok belajar $2 \quad 2 \quad 2$ 


\begin{tabular}{|c|c|c|c|c|}
\hline \multirow[t]{2}{*}{ No } & \multirow[t]{2}{*}{ Aspek yang diamati } & \multicolumn{2}{|c|}{ Penilaian } & \multirow{2}{*}{$\begin{array}{l}\text { Rata- } \\
\text { rata }\end{array}$} \\
\hline & & $\mathrm{P} 1$ & $\mathrm{P} 2$ & \\
\hline & \multicolumn{4}{|l|}{ B. Kegiatan inti } \\
\hline & $\begin{array}{l}\text { 1. Mempresentasik } \\
\text { an langkah- } \\
\text { langkah metode } \\
\text { pembelajaran } \\
\text { kooperatif }\end{array}$ & 2 & 2 & 2 \\
\hline & $\begin{array}{l}\text { 2. Membimbing } \\
\text { siswa } \\
\text { melakukan } \\
\text { kegiatan }\end{array}$ & 3 & 3 & 3 \\
\hline & $\begin{array}{l}\text { 3. Melatih } \\
\text { keterampilan } \\
\text { kooperatif }\end{array}$ & 2 & 2 & 2 \\
\hline & 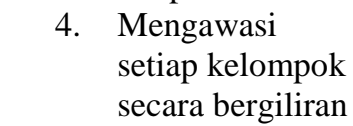 & 3 & 3 & 3 \\
\hline & $\begin{array}{l}\text { 5. } \\
\text { bemberikan } \\
\text { kelompok kepada } \\
\text { mengalami } \\
\text { kesulitan }\end{array}$ & 2 & 3 & 2,5 \\
\hline & \multicolumn{4}{|l|}{ C. Penutup } \\
\hline & $\begin{array}{l}\text { 1. Membimbing } \\
\text { siswa membuat } \\
\text { rangkuman }\end{array}$ & 3 & 3 & 3 \\
\hline & $\begin{array}{l}\text { 2. Memberikan } \\
\text { evaluasi }\end{array}$ & 3 & 2 & 2,5 \\
\hline II & Pengelolaan Waktu & 2 & 2 & 2 \\
\hline II & Antusiasme Kelas & & & \\
\hline \multirow[t]{3}{*}{ I } & 1. Siswa antusias & 2 & 2 & 2 \\
\hline & 2. Guru antusias & 3 & 2 & 2 \\
\hline & Jumlah & 30 & 29 & 31 \\
\hline
\end{tabular}

Berdasarkan tabel 1 di atas didapatkan ratarata keterlaksanaan metode pembelajaran information search adalah 2,38 dengan kategori kurang baik. Hal ini terjadi karena guru masih agak kaku dalam menerapkan metode pembelajaran tersebut yang tidak biasa diterapkan di MTs Darul Amin Palangka Raya.

Tabel 2 Rekapitulasi Hasil Tes Siklus I

\begin{tabular}{lll}
\hline No & Uraian & Hasil Siklus \\
& & I \\
\hline 1 & Nilai rata-rata tes formatif & 72,56 \\
2 & Jumlah siswa yang tuntas & 6 \\
3 & belajar & $22,22 \%$ \\
& Persentase ketuntasan belajar & \\
\hline
\end{tabular}

Berdasarkan Tabel 2 di atas aspek-aspek yang mendapatkan kriteria kurang baik adalah memotivasi siswa, menyampaikan tujuan pembelajran, pengelolaan waktu, dan siswa antusias. Keempat aspek yang mendapat nilai kurang baik di atas, merupakan suatu kelemahan yang terjadi pada siklus 1 dan akan dijadikan bahan kajian untuk refleksi dan revisi yang akan dilakukan pada siklus 2 .

Berdasarkan tabel 2 dapat dijelaskan bahwa dengan menerapkan metode pembelajaran Information Search diperoleh nilai rata-rata prestasi belajar siswa adalah 70 dan ketuntasan belajar mencapai $22,22 \%$ atau ada 6 siswa dari 39 siswa sudah tuntas belajar. Hasil tersebut menunjukkan bahwa pada siklus pertama secara klasikal siswa belum tuntas belajar, karena siswa yang memperoleh nilai $\geq 70$ hanya sebesar $22,22 \%$. Hal ini disebabkan karena siswa masih merasa baru dan belum mengerti apa yang dimaksudkan dan digunakan guru dengan menerapkan metode pembelajaran information search.

Hasil refleksi pada proses belajar mengajar dengan penerapan pembelajaran Information Search pada siklus I adalah sebagai berikut: (1) Selama proses belajar mengajar guru telah melaksanakan sintaks pembelajaran, namunbelum maksimal karena ada beberapa aspek yang dilakukan dengan harus melihat perencanaan pembelajaran. (2) Berdasarkan data hasil pengamatan diketahui bahwa siswa belum semua aktif selama proses belajar berlangsung. (3) Hasil belajar siswa pada siklus I belum $100 \%$ mencapai ketuntasan. Hasil refleksi pada siklus I bahwa guru telah menerapkan pembelajaran Information Search dengan kurang baik dan dilihat dari aktivitas siswa serta hasil belajar siswa pelaksanaan proses belajar mengajar masih belum tuntas secara keseluruhan maka diperlukan revisi agak banyak.

\section{Siklus II}

Tahap perencaan pada siklus II telah dilakukan melalui persiapan perangkat pembelajaran yang terdiri dari rencana pelajaran 2, LKS 2, soal tes formatif II, dan alat-alat pengajaran yang mendukung. Adapun data hasil penelitian pada siklus II adalah seperti terlihat pada table 3 . 
Tabel 3. Pengelolaan Pembelajaran pada Siklus

II

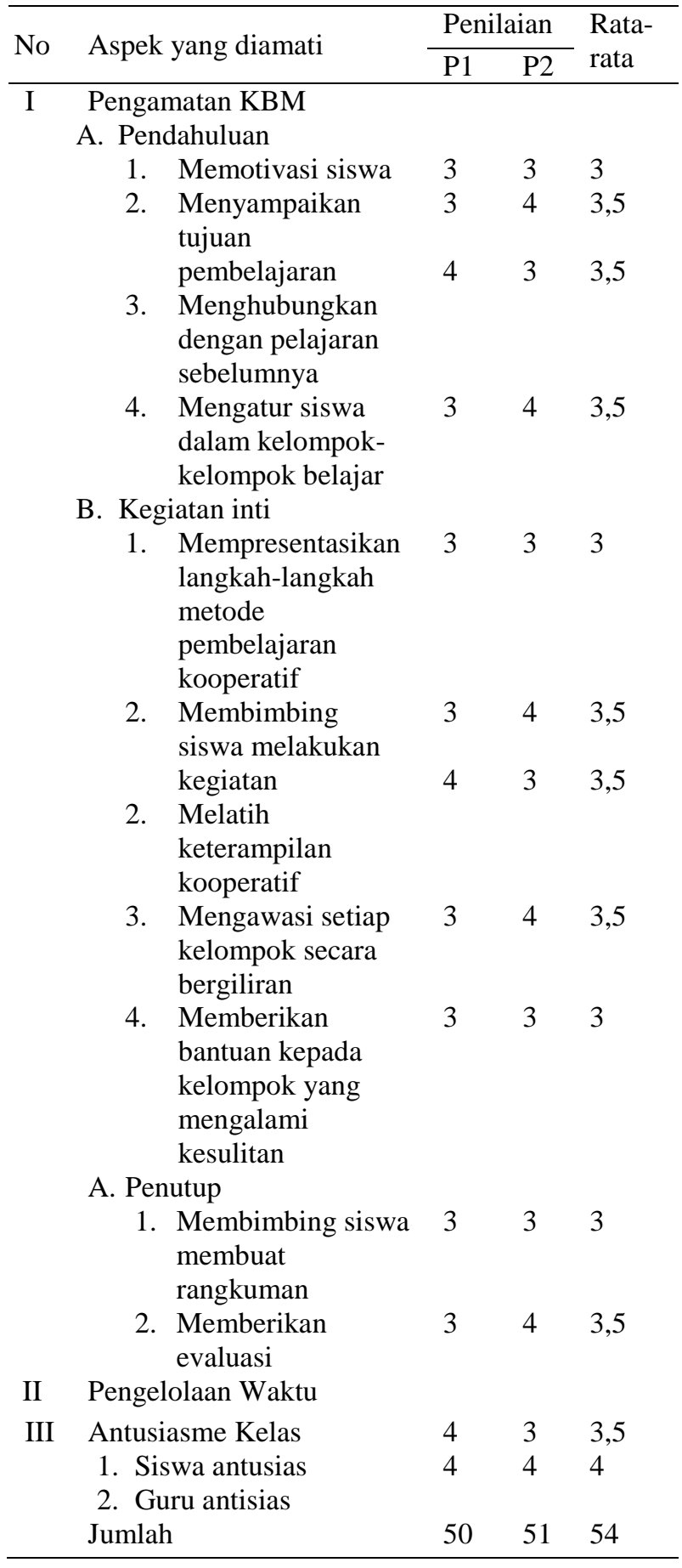

Berdasarkan tabel 3 bahwa aspek-aspek yang diamati pada kegiatan belajar mengajar pada siklus II yang dilaksanakn oleh guru dengan menerapkan metode pembelajarn information search mendapatkan penilaian yang cukup baik (rata-rata 3,3 ) dari pengamat. Meskipun demikian, penilaian tesebut belum merupakan hasil yang optimal, untuk itu ada beberapa aspek yang perlu mendapatkan perhatian untuk penyempurnaan penerapan pembelajaran selanjutnya. Aspek-aspek tersebut adalah memotivasi siswa, membimbing siswa merumuskan kesimpulan/ menemukan konsep, dan pengelolaan waktu. Rekapitulasi hasil belajar pada siklus kedua adalah seperti terlihat pada table 4 .

Tabel 4 Rekapitulasi Hasil Tes Siklus II

\begin{tabular}{clc}
\hline No & \multicolumn{1}{c}{ Uraian } & Hasil Siklus II \\
\hline 1 & Nilai rata-rata tes formatif & 73 \\
2 & Jumlah siswa yang tuntas & 29 \\
3 & belajar & $74 \%$ \\
& Persentase ketuntasan belajar & \\
\hline
\end{tabular}

Berdasarkan tabel 4 di atas diperoleh nilai rata-rata prestasi belajar siswa adalah 73 dan ketuntasan belajar mencapai $74 \%$ atau ada 29 siswa dari 39 siswa sudah tuntas belajar. Hasil ini menunjukkan bahwa pada siklus II ini ketuntasan belajar secara klasikal telah megalami peningkatan sedikit lebih baik dari siklus I. Adanya peningkatan hasil belajar siswa ini karena setelah guru menginformasikan bahwa setiap akhir pelajaran akan selalu diadakan tes sehingga pada pertemuan berikutnya siswa lebih termotivasi untuk belajar. Selain itu siswa juga sudah mulai mengerti apa yang dimaksudkan dan diinginkan guru dengan menerapkan metode pembelajaran Information Search.

Hasil refleksi yang telah diperoleh dari siklus II adalah (1) Selama proses belajar mengajar guru telah melaksanakan sintak pembelajaran dengan baik walaupun ada beberapa aspek yang belum sempurna. (2) Sebagian besar siswa mulai terlihat aktif selama proses belajar berlangsung. (3) Kekurangan pada siklus I sudah diperbaiki sehingga hasil belajar siswa pada siklus II $74 \%$ mencapai ketuntasan.

Hasil refleksi pada siklus III menunjukkan bahwa guru telah menerapkan pembelajaran Information Search dengan baik dan dilihat dari aktivitas siswa serta hasil belajar siswa pelaksanaan proses belajar mengajar sudah berjalan dengan baik. Maka tidak diperlukan revisi terlalu banyak, tetapi yang perlu diperhatikan untuk tindakan selanjutnya adalah memaksimalkan dan mepertahankan apa yang telah ada dengan tujuan agar pada pelaksanaan proses belajar mengajar selanjutnya penerapan pembelajaran Information 
Search dapat meningkatkan proses belajar mengajar sehingga tujuan pembelajaran dapat tercapai.

\section{Siklus III}

Perencanaan di siklus III telah dilakukan oleh peneliti meliputi persiapan perangkat pembelajaran yang terdiri dari rencana pelajaran 3 , LKS 3, soal tes formatif 3, dan alat-alat pengajaran yang mendukung. Proses belajar mengajar mengacu pada rencana pelajaran dengan memperhatikan revisi pada siklus II, sehingga kesalahan atau kekurangan pada siklus II tidak terulang lagi pada siklus III. Pengamatan (observasi) dilaksanakan bersamaan dengan pelaksanaan belajar mengajar. Adapun data hasil peneitian pada siklus III adalah sebagai berikut:

\section{Tabel 5 Pengelolaan Pembelajaran pada Siklus} III

\begin{tabular}{|c|c|c|c|c|}
\hline \multirow{2}{*}{ No } & \multirow{2}{*}{ Aspek yang diamati } & \multicolumn{2}{|c|}{ Penilaian } & \multirow{2}{*}{$\begin{array}{l}\text { Rer } \\
\text { ata }\end{array}$} \\
\hline & & $\mathrm{P} 1$ & $\mathrm{P} 2$ & \\
\hline \multirow[t]{17}{*}{ I } & Pengamatan KBM & & & \\
\hline & A. Pendahuluan & & & \\
\hline & 1. Memotivasi siswa & 4 & 4 & 4 \\
\hline & $\begin{array}{l}\text { 2. Menyampaikan } \\
\text { tujuan pembelajaran }\end{array}$ & 4 & 4 & 4 \\
\hline & $\begin{array}{l}\text { 3. Menghubungkan } \\
\text { dengan pelajaran } \\
\text { sebelumnya }\end{array}$ & 4 & 4 & 4 \\
\hline & $\begin{array}{l}\text { 4. Mengatur siswa } \\
\text { dalam kelompok- } \\
\text { kelompok }\end{array}$ & 4 & 4 & 4 \\
\hline & B. Kegiatan inti & & & \\
\hline & $\begin{array}{l}\text { 1. Mempresentasikan } \\
\text { langkah-langkah }\end{array}$ & 4 & 4 & 4 \\
\hline & metode pembelajaran & 4 & 3 & 3,5 \\
\hline & kooperatif & 3 & 4 & 4 \\
\hline & $\begin{array}{l}\text { 2. Membimbing siswa } \\
\text { melakukan kegiatan }\end{array}$ & 4 & 3 & 3,5 \\
\hline & $\begin{array}{l}\text { 3. Melatih keterampilan } \\
\text { kooperatif }\end{array}$ & 3 & 4 & 3,5 \\
\hline & $\begin{array}{l}\text { 4. Mengawasi setiap } \\
\text { kelompok secara } \\
\text { bergiliran }\end{array}$ & & & \\
\hline & $\begin{array}{l}\text { 5. Memberikan bantuan } \\
\text { kepada kelompok } \\
\text { yang mengalami } \\
\text { kesulitan }\end{array}$ & & & \\
\hline & C. Penutup & & & \\
\hline & 1. Membimbing siswa & 4 & 4 & 4 \\
\hline & $\begin{array}{l}\text { membuat rangkuman } \\
\text { 2. Memberikan evaluasi }\end{array}$ & 4 & 4 & 4 \\
\hline II & Pengelolaan Waktu & 4 & 4 & 4 \\
\hline
\end{tabular}

\begin{tabular}{llccc}
\hline \multirow{2}{*}{ No } & Aspek yang diamati & \multicolumn{2}{c}{ Penilaian } & Rer \\
\cline { 3 - 4 } & P1 & P2 & ata \\
\hline \multirow{3}{*}{ III } & Antusiasme Kelas & & & \\
& 1. Siswa antusia & 4 & 4 & 4 \\
& 2. Guru antisias & 4 & 4 & 4 \\
& Jumlah & 54 & 54 & 55,5 \\
\hline
\end{tabular}

Dari tabel 5 di atas, dapat dilihat aspek-aspek yang diamati pada kegiatan belajar mengajar (siklus III) yang dilaksanakan oleh guru dengan menerapkan metode information search mendapatkan penilaian baik (rata-rata 3,9) dari pengamat adalah memotivasi siswa, membimbing siswa merumuskan kesimpulan/menemukan konsep, dan pengelolaan waktu. Rekapitulasi hasil tes formatif pada siklus 3 adal seperti terlihat pada tabel 6.

\section{Tabel 6 Rekapitulasi Hasil Tes Siklus III}

\begin{tabular}{clc}
\hline No & \multicolumn{1}{c}{ Uraian } & $\begin{array}{c}\text { Hasil } \\
\text { Siklus III }\end{array}$ \\
\hline 1 & Nilai rata-rata tes formatif & 82 \\
2 & Jumlah siswa yang tuntas & 37 \\
3 & belajar & $94 \%$ \\
& Persentase ketuntasan belajar & \\
\hline
\end{tabular}

Berdasarkan tabel 6 dapat dilihat bahwa nilai rata-rata tes formatif sebesar 82 dan dari 39 siswa yang telah tuntas sebanyak 37 siswa dan 2 siswa belum mencapai ketuntasan belajar. Maka secara klasikal ketuntasan belajar yang telah tercapai sebesar 94\% (termasuk kategori tuntas). Hasil pada siklus III ini mengalami peningkatan lebih baik dari siklus II. Adanya peningkatan hasil belajar pada siklus III ini dipengaruhi oleh adanya peningkatan kemampuan guru dalam menerapkan pembelajaran Information Search sehingga siswa menjadi lebih terbiasa dengan pembelajaran seperti ini sehingga siswa lebih mudah dalam memahami materi yang telah diberikan. Pada siklus III ini ketuntasan secara klasikal telah tercapai, sehingga penelitian ini hanya sampai pada siklus III.

Tahap refleksi pada siklus III telah terlaksana dengan baik yaitu (1) Selama proses belajar mengajar guru telah melaksanakan semua sintaks pembelajaran dengan sangat baik. (2) Berdasarkan data hasil pengamatan bahwa siswa aktif selama proses belajar berlangsung. (3) Kekurangan pada siklus-siklus sebelumnya sudah diperbaiki sehingga menjadi lebih baik. (4) Hasil belajar siswa pada siklus III mencapai ketuntasan. 
Keterlaksanaan siklus III terlihat bahwa guru telah menerapkan metode pembelajaran information search dengan baik. Aktivitas siswa dalam proses belajar mengajar sudah berjalan dengan baik dan hasil belajar siswa telah mengalami peningkatan pada setiap siklusnya. Dengan demikian, metode information search dapat meningkatkan proses belajar mengajar sehingga tujuan pembelajaran dapat tercapai. Senada dengan hasil penelitian Japar (2009) menunjukkan bahawa metode Informatiaon Search dapat meningkatkan motivasi siswa, aktivitas siswa dan hasil belajar siswa. Selanjutnya, hasil penelitian Fariidah (2011) mengatakan bahwa penerapan kolaborasi strategi pembelajaran LSQ (Learning Start WithA Question) dan IS (Information Search) berperan efektif terhadap hasil belajar siswa.

Peneilitian ini menunjukkan bahwa pembelajaran information search memiliki dampak positif dalam meningkatkan prestasi belajar siswa. Hal ini dapat dilihat dari semakin mantapnya pemahaman siswa terhadap materi yang disampaikan guru (ketuntasan belajar meningkat dari sklus I, II, dan II) yaitu masing-masing $22,22 \%, 74 \%$, dan 94\%. Pada siklus III ketuntasan belajar siswa secara klasikal telah tercapai.

Aktivitas siswa dalam proses pembelajaran menggunakan metode information search dalam setiap siklus mengalami peningkatan. Hal ini berdampak positif terhadap prestasi belajar siswa yaitu dapat ditunjukkan dengan meningkatnya nilai rata-rata siswa pada setiap siklus yang terus mengalami peningkatan. Aktivitas siswa dalam proses pembelajaran Sejarah Kebudayaan Islam pada pokok bahasan sumber daya alam yang paling dominan adalah bekerja dengan menggunakan alat/media, mendengarkan/ memperhatikan penjelasan guru, dan diskusi antar siswa/antara siswa dengan guru. Jadi dapat dikatakan bahwa aktivitas siswa dapat dikategorikan aktif.

Aktivitas guru selama pembelajaran telah melaksanakan langah-langkah pembelajaran information search dengan baik, hal ini terlihat dari aktivitas guru yang muncul diantaranya aktivitas membimbing dan mengamati siswa dalam mengerjakan kegiatan LKS/menemukan konsep, menjelaskan/melatih menggunakan alat, memberi umpan balik/evaluasi/tanya jawab dimana prosentase untuk aktivitas di atas cukup besar.

\section{Kesimpulan}

Berdasarkan hasil pembahasan dan analisis yang telah dilakukan, penelitian ini dapat disimpulkan bahwa: (1) Keterlaksanaan penerapan metode pembelajaran information search mengalami perbaikan secara gradual pada setiap siklusnya yaitu dari kondisi kurang baik menjadi kondisi baik. (2) Pembelajaran dengan metode information search memiliki dampak positif dalam meningkatkan prestasi belajar siswa yang ditandai dengan peningkatan ketuntasan belajar siswa dalam setiap siklus, yaitu siklus I (64\%), siklus II (74\%), siklus III (94\%).

\section{Saran}

Ada beberapa saran yang disampaikan peneliti dalam penelitian ini adalah (1) Untuk melaksanakan metode information search memerlukan persiapan yang cukup matang, sehingga guru harus mampu menentukan atau memilih topik yang benar-benar bisa diterapkan dengan metode information search dalam proses belajar mengajar sehingga diperoleh hasil yang optimal. (2) Dalam rangka meningkatkan prestasi belajar siswa, guru hendaknya lebih sering melatih siswa dengan berbagai metode pembelajaran, walau dalam taraf yang sederhana, dimana siswa nantinya dapat menemukan pengetahuan baru, memperoleh konsep dan keterampilan, sehingga siswa berhasil atau mampu memecahkan masalah-masalah yang dihadapinya.

\section{Daftar Pustaka}

Asyachowi, A. H. (2011). Upaya meningkatkan kemandirian belajar siswa pada mata pelajaran PAI pokok bahasan Hukum Nun Mati/Tanwin dan Mim Mati melalui model information search (penelitian tindakan pada siswa kelas VII A SMP Negeri 31 Semarang tahun ajaran 2009/2010) (Doctoral dissertation, IAIN Walisongo).

Fariidah, J. (2011). Efektivitas kolaborasi strategi pembelajaran LSQ (Learning Start with a Question) dan IS (Information Search) terhadap hasil belajar siswa pada materi pokok filum chordata kelas X MA Mazro'atul 
Huda di Demak tahun pelajaran 2010/2011 (Doctoral dissertation, IAIN Walisongo).

Hermanto, D. T. (2013). Peningkatan Minat Belajar Melalui Strategi Information Search Dalam Pembelajaran Ips Siswa Kelas IV SD Negeri Monggot 2 Geyer Grobogan Tahun Ajaran 2012/2013 (Doctoral dissertation, Universitas Muhammadiyah Surakarta).

Inayah, R. (2013). Pengaruh kompetensi guru, motivasi belajar siswa, dan fasilitas belajar terhadap prestasi belajar mata pelajaran ekonomi pada siswa kelas XI IPS SMA Negeri 1 Lasem Jawa Tengah Tahun Pelajaran 2011/2012. Jurnal pendidikan insan mandiri, 2(1).

Jafar, M. (2009). Penerapan Strategi LSQ (Learning Start With a Question) dan IS (Information Search) pada Pembelajaran Biologi untuk Meningkatkan Motivasi, Aktivitas, dan Hasil Belajar Siswa (Doctoral dissertation, Universitas Negeri Semarang).

Majid, A. (2017). Pengaruh Strategi Pembelajaran Kooperatif Model Student Teams Achievement Division (STAD) Dan Motivasi Belajar Siswa Terhadap Prestasi Belajar Sejarah Kebudayaan Islam Pada Siswa Di Mi Mabdaul Huda Kedungbang Kecamatan Tayu Kabupaten Pati (Doctoral dissertation, STAIN Kudus).

Sinambela, P. N. (2017). Faktor-Faktor Penentu Keefektifan Pembelajaran dalam Model Pembelajaran Berdasarkan Masalah (Problem Based Instruction). Generasi Kampus, 1(2).

Werdayanti, A. (2008). Pengaruh Kompetensi Guru dalam Proses Belajar Mengajar di Kelas dan Fasilitas Guru Terhadap Motivasi Belajar Siswa. Dinamika Pendidikan, 3(1).

Widyaningrum, R. (2011). Penerapan Active Learning Dengan Metode Information Search Untuk Meningkatkan Aktivitas Belajar Biologi Siswa Kelas X-11 SMA Negeri 1 Sukoharjo Tahun Pelajaran 2010/2011. Jurnal ilmu pendidikan(online) http://biologi. fkip. uns. ac. id/wp-content/uploads/2011/05/17-x. $\quad$ pdf. Diakses, 15. 